\title{
Gender Dynamics of Drug Problem in Brazil
}

\author{
Kazi Md. Mukitul Islam (Master's Candidate) \\ Department of Development Studies, Faculty of Economics and Administration \\ University of Malaya, Kuala Lumpur, Malaysia; Email:mukitul.raj@gmail.com

\section{Md. Arphan Ali (PhD Candidate)} \\ Department of Economics, Faculty of Economics and Administration \\ University of Malaya, Kuala Lumpur, Malaysia; Email:arphan2iium@gmail.com
}

\section{Doi:10.5901/mjss.2016.v7n2s1p52}

\begin{abstract}
The purpose of this paper is to identify gender dynamics of drug problem among the female population of Brazil. Given the rising phenomenon of feminization of drug consumption and business, the risk incurred on them is much more than their male counterparts. This study adopts exploratory descriptive research with qualitative technique that includes survey data within Brazilian States. The findings of this study show that the causes of involvement of female drug users are not always same as for men and also its impact within social spectrum of Brazilian society. Beside physical vulnerabilities, breaking down of family, rising prostitution, incarceration are major side effects of drug abuse among females. It also finds out that loopholes within prevention mechanisms not only make women more vulnerable, but also delays the rehabilitation process of the drug users in Brazil. This study suggests that pragmatic role of education, law and religion can be the cornerstone to reduce gender dynamics of drug problems in Brazil.
\end{abstract}

Keywords: Gender, Drug, Feminization, Brazil

\section{Introduction}

The global consumption of illicit drug and trafficking show upward trend in recent years despite undertaking of international and national level preventions. According to the World Drug Report 2014, 243 million people between age 15-64 used illicit drugs in 2012 (UNODC, 2014, p.1)though six years ago it was only 208 million. Beside, the percentage of people involved in consumption of illicit drug increased from 4.3\% in 2006 to 5.2\% in 2012. The activities related to drug not only cause physical harm, but also spread negative externalities among individuals and society. The burden of disease as a result of drug use is very high around the world. An estimated numbers of 183,000 drug related deaths were reported in 2012 (UNODC, 2014, p.4). This indicates a mortality rate of 40 deaths per 1 million people aged 15-64 (in USA this rate is 142 per million and in Latin America 15 per million).Moreover, $13.1 \%$ out of the 12.7 million people who take drug through injection are living with HIV. According to recent study, in 2010 alone 1,980,000 (1.9 million) years of life were lost as a result of HIV infection in conjunction with unsafe drug injection (Global Burden of Disease Study2010as cited in White ford et al. 2013). However, even though women are more visible these days in drug related activities, the international data regarding women and their drug use is very rare to find. The policy brief report of UN Women (2014, p.2) highlights that in general; men use 2-3 times more drug than women around the world. While, women enter drug trade for a number of causes like social exclusion, gender related violence, sexism, poverty, single parenthood etc. (Giacomello, 2014). Consequently, they often face gender specific cruelty in drug related activities. For instance, women not only hold low ranking posts (with low payment), but also forced to have sexual relationship with members as part of initiation of drug business (UN Women, 2014, p.3). As a result, unwanted pregnancy, poor birth outcome and child abuse are common burden faced by women which is not experienced by male members. Nevertheless, social stigma faced by women often lead to discrepancy in treatment facility for them. Study finds that in Europe, the treatment ratio of men and women drug users was 4:1 in 2010 (as cited in UN Women, 2014, p.2).

Federative Republic of Brazil, the $5^{\text {th }}$ largest county in the world by population (200.4 million people according to the World Bank data) constitutes more than half of the population of South America. Brazil also a country with high vulnerability due to increasing crack and other illicit drug use. The first National Household Survey (2001) shows that $19.8 \%$ people in Brazil have consumed some kind of illicit drug (excluding alcohol and tobacco) in their lifetime, while $68.7 \%$ have consumed alcohol and $41 \%$ consume tobacco (Carlini et al 2002). Where, the second household survey in 
2005 shows increase in the overall drug consumption in Brazil, alcohol $74.6 \%$ and tobacco $44 \%$, while cocaine consumption increased to 2.9\% from 2.3\% (cited in Misse\& Vargas, 2010, p.97). Unlike other South American countries, the cocaine consumption in Brazil increased since 2005 (the average cocaine consumption in Brazil is four times higher than average global cocaine consumption, Miraglia, 2015, p.3). The study conducted by Bertoniet al. (2014) in 27 Brazilian capital cities shows that the prevalence of drug use is very high among those who are young, under housed and socio-economically marginalized. Besides, men and women with lower education have more prevalence of drug use. Study of Silva et al. (2009) shows that, those with 8 years of schooling consume $8 \%$ more tobacco than those with one extra year of schooling in Brazil.

On the other hand, Brazil is a neighbor to the world's biggest cocaine-producing countries (e.g., Peru, Bolivia) and dear to the most cocaine-consuming country in the world (i.e., USA). The rippling effect of regional drug cartel not only touches the border of Brazil, but also the core of its society where number of drug addicts is increasing over the years. Brazilian economy grew faster over the years, but the rising tide did not lift all the boats. Rather, it created high level of inequality among different classes. Moreover, the growing corruption among government officials has only produced futile policies over the years. These loopholes in social, economic and judicial system have made Brazil not only the second largest cocaine consumer in the world, but also high rate of homicide and growing rate of incarceration in the World. Furthermore, abusive law and patriarchal norm makes this even worse for women who often fall prey to this line of business. The changing role of women and entrance in the drug business breaking down the family structure and leaving the task of child rearing in the hands of no one. Therefore, the main purpose of this study is to investigate the rising trend of women involvement in drug consumption in Brazil.

Given this background, this paper is organized as follows. The first section of the paper expounds overall global scenario of drug consumption and its effects, followed with Brazilian context. The second section explains about the Methodology. The third section discusses gender dynamics of drug consumption in Brazil, its causes and consequence between both the sexes. The fourth section highlights loopholes of three preventive mechanisms (e.g., social norm, law and rehabilitation center). The paper finishes with few policy suggestions, gender specific as well as overall for solving drug problem in Brazil.

\section{Methodology}

This is an exploratory-descriptive study with a qualitative approach based on findings from first nationwide survey in the 27 Brazilian state capitals (SENAD 2010), four broad surveys between 1987 to 1997 (Galduroz et al. 2004), two university surveys in Sao Paulo (Wagner et al. 2007), the World Drug Report (UNODC 2014), Brazilian drug policy report (Ribeiro et al 2014), UN Women policy brief paper (UNWOMEN 2014), Human Rights Report: Brazil 2009, Global Status Report: Alcohol and Young People and lastly, the report of World Health Organization (Jernigan, H.D., 2001).

The reason for choosing Galduroz et al (2004) was because it covers longer (10 state capitals) and multiple surveys (total four) that allows us to identify the trend in the drug consumption. The study of SENAD (2010) is more comprehensive as well as updated version than the previous one including 27 state capitals in Brazil. While, The World Drug report 2014 provides nation specific statistics about drug consumption around the world. For policy purpose, study of UN Women and Ribeiro et al are two comprehensive studies on drug problem in Brazil. The Human Rights Report and Global Status Report are incorporated because it covers multidimensional approach into drug problem around the world and in Brazil.

\section{Gender Dynamics Ofillicit Drug Consumption}

"Involvement with drugs socially considered male conduct" (Souza et al. 2014, p 93). However in Brazil, consumption of drug is growing (especially psychoactive substance use) among females as well. In their recent report, Gender Across Border (GAB, 2011) describes feminizing pattern of drug war with increasing presence of women as workers as well as in leadership fronts in Latin America. In Brazil alone (the second most cocaine consumed country after USA), 10,000 women are doing time for drug related smuggling(GAB, 2011). This rising trend also evident among female students as well.

\subsection{Drug consumption among the students}

The study conducted by Bertoniet al. (2014) shows that drug consumption is negatively related with education levelin Brazil. Conversely, a number of studies on students disprove this generalization (e.g.,Wagneret al., 2007; Galdurozet al., 
2004 etc.). The table below illustrates gender specific summary of illicit substance consumption among students in Brazil. The overall findings from these reports suggest a rising trend of drug consumption of various types between both the sexes (male's students slight higher than female students on an average).

Table 1: Studies on illicit drug consumption among male and female students in Brazil

\begin{tabular}{|l|c|c|c|c|c|c|c|c|c|c|}
\hline Year & \multicolumn{2}{|c|}{1987} & \multicolumn{2}{c|}{1996} & \multicolumn{2}{c|}{1997} & \multicolumn{2}{c|}{2001} & \multicolumn{2}{c|}{2010} \\
\hline Gender & Male & Female & Male & Female & Male & Female & Male & Female & Male & Female \\
\hline Lifetime college student & & & $42.9 \%$ & $34.5 \%$ & & & $47.9 \%$ & $41.3 \%$ & $63 \%$ & $54.5 \%$ \\
\hline Last 12 months & & & $31.1 \%$ & $23.7 \%$ & & & $34.2 \%$ & $27.1 \%$ & $41.1 \%$ & $34.9 \%$ \\
\hline Last 30 days & & & $19.1 \%$ & $14.8 \%$ & & & $24.9 \%$ & $17.5 \%$ & $29.7 \%$ & $25.6 \%$ \\
\hline Life time secondary school & $21.9 \%$ & $20.6 \%$ & & & $26.8 \%$ & $22.9 \%$ & & & & \\
\hline & & & & & & & & & & \\
\hline
\end{tabular}

Source: Wagner et al. (2007), SENAD (2010) and Galdurozet al. (2004)

According to a household survey in 2005, one in every five Brazilian takes some kind of psychoactive drugs (Carlini et al. 2007). However, from the table above, both the quantity and intensity of drug use among youth group is much higher than the national rate (see table 1). The table summarizes drug consumption among students from three national survey reports $^{1}$. The table shows that consumption of illicit drug has increased between both the genders over the years. Lifetime consumption of drug among college female students rose exactly 20-percentage point between 1996-2010 (from $34.5 \%$ in 1996 to 54.5\%). Almost same rise is evident among male students. However, rise in the last 12 months is higher among the female students (11.2 percentage point) than male (10.0 percentage point). Similarly, rising trend among female students in data comprising drug use inlast30 days is slightly higher than male counterpart between 1996-2010 (i.e. rose at 10.8 percentage point compared to 10.6 for male students). However, the data among slightly younger population (age between 15-18) shows that the consumption is more in rise among male students than female in four surveys between 1987-1997 (4.9 percentage point compared to 2.3 percentage point for female students).

On the other hand, the table below shows substance specific drug consumption pattern where male users exceed female users in Alcohol, Tobacco, Marijuana, Cocaine and Crack consumption between 1996-2010 (see table 2). While female users surpass male students in substances like Tranquilizers, Analgesics and Amphetamine. Both the genders show high consumption pattern in Alcohol (between 80-90\%), then followed by Tobacco and Marijuana. According to Population Reference Bureau report (PRB 2013, p.8), around 50.7 million citizens in Brazil are between ages 10-24 $(25 \%)$ and higher percentage of female youth are enrolled in tertiary education than male (29\% compared to $22 \%)$. Therefore, the rising pattern of drug consumption not only threatens the overall youth population of Brazil in general, but also female students more specific. Given rising pattern just described above, the traditional measures for reduction of drug consumption need to be changed given rising trend of feminization of drug use in Brazil among female students.

Table 2: Lifetime consumption of different illicit drugs in Brazil

\begin{tabular}{|l|c|c|c|c|c|c|}
\hline Drugs & \multicolumn{2}{|c|}{1996} & \multicolumn{2}{c|}{2001} & \multicolumn{2}{c|}{2010} \\
\hline & Male & Female & Male & Female & Male & Female \\
\hline Alcohol & 93.7 & 87.9 & 93.5 & 89.6 & 90.3 & 83.1 \\
\hline Tobacco & 44.8 & 41.6 & 50.9 & 50.1 & 51.7 & 42.9 \\
\hline Marijuana & 33.7 & 22.3 & 39.5 & 29.5 & 34.5 & 19.9 \\
\hline Cocaine & 7.4 & 4.7 & 8.0 & 4.3 & 11.3 & 5 \\
\hline Crack & 0.8 & 0.4 & 1.4 & 0.3 & 2.1 & 0.5 \\
\hline Popular drugs among female users \\
\hline Tranquilizers and Anxiolytics & 3.1 & 6.9 & 6.5 & 8.0 & 9.3 & 14.7 \\
\hline Opiate Analgesics & 1.1 & 0.4 & 1.5 & 0.9 & 4.4 & 6.3 \\
\hline Amphetamine & 2.8 & 5.7 & 8.4 & 10 & 8.1 & 18.1 \\
\hline
\end{tabular}

Source: Wagner et al. (2007) and SENAD (2010)

1The four surveys of Galduroz et al (2004) are plotted in column one and three in first row (i.e. year 1987 and 1997), the study of Wagner among Sao Paulo university students is also plotted in column two and four (i.e. year 1996 and 2001). The last column of row one represents findings of the broadest student level survey in Brazil by SENAD (2010), conducted among college level students. 


\subsection{Causes of rising involvement in drug activities in Brazil}

From a number of recent studies (e.g., The Economist, 2013; UNODC, 2014; Miraglia, 2015) three specific causes can be identified for rising illicit drug consumption in Brazil;

- Affluence: According to the World Bank data (2015), the per capita GNI in Brazil increased from \$2,180 in 1980 to $\$ 11,690$ in 2013 that allowed her to enter in the league of Upper Middle Income countries along with Malaysia, South Africa and others.

- Urbanization: According to the World Bank data (2015), percentage of people living in urban areas in Brazil increased from $46 \%$ to $85 \%$ between 1961-2013.

- Geographical location: the border with Bolivia, Peru and Columbia is one of the factors of rising drug related crime. Out of total cocaine seized in Brazil in 2011, 99.5\% came from these three countries (Miraglia, 2015, p.3).

Besides, peer pressure, low cost and social norm etc. also influence rising drug consumption. Souza et al.(2014, p.93) cited two more specific causes for involvement of women in the drug:

- Integration into labor market: according to the World Bank data (2015), the overall participation rate of women in labor force increased from $45 \%$ in 1990 to 60\% in 2012. According to Souza et al. (2014, p.93), such incorporation of women in social and economic sphere like men also introduced habit of men (i.e. drug) among them.

- Increasing female-headed household: According to the latest data available, $20 \%$ of households are headed by female in Brazil, compared to 10\% in 1961 (The World Bank, 2015). This is approximately 11.4 million female-headed households

Moreover, studies show that women participate in drug business either by themselves (which is very rare) or due to their relationship with other males as companion, siblings or as their neighbors (Souza et al., 2014; Sentencing Council, 2011 etc.).

\subsection{Socio-economic impact of rising drug involvement}

A quit number of studies have shown correlation between drug use and HIV infection (UNODC, 2014). According to the World Bank data (2015) the prevalence of HIV in Brazil is 0.6\% (1.2 million people). Besides, 25\% of adults (around 32 million people) identified to have some sort of alcohol related disorder in Brazil (Ribeiroet al., 2014, pp.6-7). However, there are several socio-economic impact of rising drug involvement in Brazil which is discussed below.

\subsubsection{Family structure}

Among social impacts, the changing role of women not only breaking down the family structure, but also the 'Machismo culture (i.e., role of women should be only within household) of Latin America (GAB, 2011).Nevertheless, the more presence of women in this new role (even though illegal) anticipated with optimistic transformation in Latin American drug war (i.e., less violent, less brutal and more businesslike). There might be more children born in the prison for this transformation, but at least fewer people will be killed for drug dealing business.

\subsubsection{Sex workers}

Another implication of female participation in drug business is raising sex workers (prostitutes) in Brazil. Men are involved in legal (i.e., paid work) or illegal work (i.e., crime), while women commonly rely on commercial sex for income generation (Pedrosoet al., 2013). Study of Bertoniet.al. (2014) identified a number of such cases in different cities of Brazil where women have reported their involvement in unsafe sex or begging to earn money for drug consumption. Moreover, a great number of children are also getting involved into this process in Brazil. According to Federal police, there are at least 250,000 reported child prostitutes in Brazil. Besides, in one fourth of the 1,514 tourist spots studied by University of Brasilia found commercial market for child prostitutes in Brazil (as cited in US Department of State, 2009, p.9).

\subsubsection{Incarceration}

Among other implications, rising incarceration due to drug crimes is growing for both male and female in Brazil. Today, 
the total number of prison population in Brazil is 549,577 (IACHR, 2013, p.20-22). Out of them, $93.4 \%$ are male and $6.6 \%$ are female. Most of the prisoners identified to be young (69\% are between 18-34 years of age) and illiterate (45\% did not complete primary education). Nevertheless, the percentage of prisoners convicted for drug related crimes is higher for female than male ( $53 \%$ and $24 \%$ respectively) (IACHR, 2013, p.34).Even some studies have found as high as $80 \%$ female inmates convicted for drug trafficking charges (as cited in Miraglia, 2015).

According to the study of Boiteux (2011, p.36), the prison population in Brazil increased 314\% between 1992-2009 (Brazil is the fourth highest in terms of prison population after USA, China and Russia). The number of prison population outgrown the facilities available for them. Today Brazil has 170,000 more prisoners than beds available for them (Boiteux, 2011, p.36). For female prisoners, the impact of incarceration is even worse. It represents process of exclusion, discrimination and stigmatization of poor segment of population with negative repercussion for these women, their parents and children (Ventura et al., 2015, p. 608).

\subsubsection{Homicide}

Homicide is another major phenomenon in Brazil that can be related to arms and drug trafficking by organized crime groups (Miraglia, 2015, p.2). This paper shows that, in Latin America, 100,000 incidence of homicide occurs each year. According to the World Bank (2015), the rate of homicide is 24.5 (per 100,000 people) in Latin America compared to global rate of 5.2. In Brazil, this rate is even worse, at 25.2. Out of those who were imprisoned in Brazil, $6.2 \%$ for homicide cases, the majority of which are committed by male ( $97 \%$ compared to $3 \%$ by female) (IACHR, 2013).

To summaries, the graph below shows the weight of impact leaning more towards female; indicating relative high cost and liabilities as a result of drug activities by female in Brazil.

Graph 1: Weigh of impact as a result of drug related activities by male and female

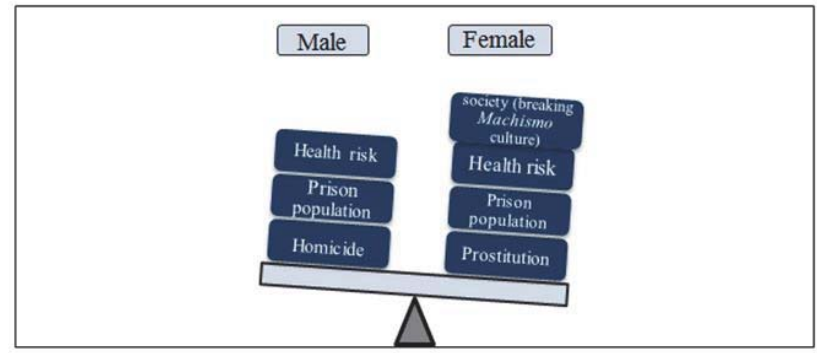

Source: Derived from discussion of impacts in previous section of this study

\section{Prevention Mechanisms}

In most of the societies, social norm (i.e. perception of good and bad), rule of law and rehabilitation centers are used for deviant members in order to bring them on the track. However, many of the panaceas convert into tools of exploitation if not executed properly. From Brazilian context, gender specific role of these three panaceas are discussed in the following part:

\subsection{Role of social Norm}

The term gender itself driven from certain social norm, especially how society view the role of men and women in its surroundings ${ }^{2}$.Everything that we value or undervalue in our life or in society has subjective and cultural meaning attached to it. Likewise in many countries, drug is part of socio-cultural norm (beyond addiction purpose). NoutheDjubganget et.al. (1995, pp.2-3) in their study shows a number of traditional uses of drugs like;Tobacco (to increase energy for hard labor), Cola (symbol of peace and friendship), Arki (during funeral and wedding time) etc.At the same

\footnotetext{
2"Gender refers to the social attributes and opportunities associated with being male and female and the relationships between women
} and men and girls and boys, as well as the relations between women and those between men". (UN Women, 2015). 
time, the paper also points out the negative consequences of the violation of traditional practices and precarious impact of excessive use of these drugs, especially for women.

This echoes with the famous quote from Plato "Excess generally causes reaction, and produces a change in the opposite direction, whether it be in the seasons, or in individuals, or in governments (cited from All about Plato, 2013). Social norm around alcohol use not only encourages, but also justifies violent acts in a society as well as violence against women (WHO, 2009, pp.5-6). Study of Ribeiroet. al(2014) also affirms such negative externalities of excessive alcohol and other drug uses in Brazilian society.

Women connected to drugs in Brazil are victim of social norm from multiple directions. Their initiation, consumption, trafficking, incarceration and rehabilitation, all are affected by power relation and gender specific implications. They are victim to both patriarchal and drug norms together. Social norm also play an important role to define type of drugs women consume. For instance, gender specific differences can be identified from a number of studies among students (see table 1) that shows tendency of women to choose specific type of drugs (e.g., amphetamines, tranquilizers etc.). This tendency can be related with the way women are brought up in our society (i.e., praised for her body appearance, rather than intelligence) that forces them choose pills in order to become 'calm and skinny' (Galdurozet. al., 2004, p.529).

\subsection{The Role of Law}

In 1940 for the first time drug became focus of attention in Brazil when the first law (Article 281 of the Penal Code) was introduced. Before this, drug was not any focus of attention in legislation or in media (Boiteux, 2011, p.30). Since then, Brazil has made a number of criminal laws (e.g., Law 4451/1966, Law 8072/1990, Law 9099/1995 etc.) for controlling drug problems and issues in the society. Among them, Law 6368/1976 and Law 11343/2006(the latest) are two of the most famous laws in Brazil. Over the years, strict imposition of law supplemented with rising number of prisoners in Brazil (see Table 3). The table below shows that the percentage of inmates for drug trafficking increased from $9.1 \%$ in 2005 to 23\% in 2013 (almost 150 percent rise within only 8 years).

Table 3: Number of prisoners in Brazil and share of imprisonment for drug trafficking

\begin{tabular}{|c|c|c|}
\hline Year & Number of Prisoners & Traffickers as percentage of prison population \\
\hline 1992 & 114,377 & ---- \\
\hline 1995 & 148,760 & ---- \\
\hline 1999 & 194,074 & --- \\
\hline 2005 & 361,402 & $9.1 \%$ \\
\hline 2006 & 383,480 & $12.3 \%$ \\
\hline 2009 & 473,000 & $19.2 \%$ \\
\hline 2013 & 549,577 & $23.0 \%$ \\
\hline
\end{tabular}

Source: Infopen (as cited in Boiteux, 2011, pp.36-37) and IACHR (2013, p.20)

However, the rising prisoners' number does not reflect real scenario of legal regime in Brazil. In Brazil, drug laws are not only contradictory to each other, but also discriminatory in its application. Studies have identified unjust and harsh implementation of drug laws, mostly on marginalized group and low ranked members of the drug trafficking chain (Boiteux, 2011; Ventura et al. 2015 etc.). The Brazilian law is like the spider web that catches the small flies and let the hawk go free. Consequently, it imposes high cost of incarceration over the years on government budget, without actually making any radical change that requires incarceration of the leaders in drug business. In general, every detainee has the right to be presumed innocent until proven guilty. They are also entitled by law to be represented by a lawyer on their choice or at public expense. Despite this, in reality the publicly funded legal aid is frequently limited or non-existent. For women, this situation is even worse (who lack resources to pay for legal representation and the knowledge of the law and courts) (Miraglia, 2015). The report also shows that one third of the incarcerated women (34\%) are kept provisional, before convicted by the judiciary (Ventura et al., 2015).

Moreover, this study also identifies 33 different laws in Brazil for imprisonment of women. As a result of the rising incarceration of women (majority for drug crimes) related with increasing phenomenon of jail babies. Unfortunately in prison, the real evidence is absent for the right to breastfeeding (as imposed by constitution of Brazil) and other aspects of motherhood that makes imprisonment a double penalty for these women (Ventura et al. 2015, p. 607-608). 


\subsection{The Role of Rehabilitation center}

The Fourth World Conference on Women in 1995 focused specific attention to the" access to appropriate treatment and rehabilitation services for women substance abusers and their families" (Paragraph 106(v) as cited in Hsu \& Guerney, 1995, p.10). In Brazil, mutual-help groups (Alcoholics Anonymous (AA), Tough Love), religious support groups (Sobriety Ministries, Jewish Alcoholics etc.) and Street Offices are present in almost all cities, yet they have not been sufficiently studied with reference to the public health system (Ribeiro et al., 2014, p.16). Reference of rehab is identifiable only in very few studies (e.g., Hsu \&Guerny, 1995; Ventura et al. 2015 etc.). Due to this lack of data, it is hard to say anything about rehab services generally.

Moreover, according to Hsu \& Guerny (1995), even though women are highly visible in drug related activities, yet social attitude lead to concealment of the problems related to women. Rehab and inpatient centers do not admit women who are pregnant and have HIVIAIDS. Lack of sex segregated accommodation and lack of experts in dealing with such cases often discourage addicted. As a result, the problems faced by women remain under reported and leading to scarcity of data regarding women (Hsu \&Guerny, 1995, p.2).

\section{Policy Suggestions}

$>$ Role of Education: Studies have shown that the addiction level as well as incarceration is very high among the people who are illiterate or less educated in Brazil. However, high addiction also prevalent among the students at all level as well. This dual nature of role of education indicates the lack of awareness and drug education among Brazilian population. Drug and its impact needs to be incorporated in national curriculum, television programs, radio broadcasting in order for Brazilians to grow aversion on drug abuse. Besides, Studies have shown that the advertising of drug and promoting women (i.e., body appearance) in the media have negative consequence in the society, especially for women in Brazil who are entering into the job market in increasing rate. This attitude towards women and their body appearance needs to be modified very soon.

$>$ Role of Religion: The study of Sanchez et al. (2011) identified one of the unique findings that students with good faith in god and involved with church has low tendency for drug use, compare to those who don't have these affiliation. Sinha et al. (1990) also affirms this result that adolescence those who attended religious services show least exposure to alcohol (as cited in Sanchez et al., 2011, p. 9). Unfortunately for Brazil, The religious practice reducing over the last few decades. According to Pew Research Center (2013) report, the percentage of people follows Roman Catholic religion reduced from 65\% to 92\% between 1970-2010 (biggest decline among youth group). While people with non-affiliation with religion increased from 0.7 million to 15 million during this time.

Even though many religion service groups are working, but less productive in outcome. It requires recognition of the importance of religion in context of current situation. More activities in church, in mosque or in synagogue centers will keep the followers with better peer groups who have low addictive nature. Besides, through regular practice within the family structure and encouragement in education system can also help to cure the drug disease from the heart of young Brazilians who are getting less empathetic towards religion.

$>$ Role of Law: Misuse of law has resulted into counterproductive incidences in Brazil. Laws should be for the people, not the people for law. Rather than catching the marginalized groups (e.g. women and uneducated poor etc., who are often forced into this business), the enforcement of law must target the godfathers in order to bring radical transformation in drug business. Besides, the detainees should be given proper services to defend their cause. Especially for pregnant inmates, who hardly get facilities to breastfeed their babies, let alone education and health services. Prison and rehab centers should focus on reconstructing the habit of the addicted or felons, rather than setting ground for worse outcome within prison or rehab centers.

Besides, the reduction of drug among women also requires reduction of sex work that provides money for female addicts. According to Bertoniet al. (2014,p.6), the policy for drug requires reduction of sex work in order to improve the related harm among female crack users.

\section{Conclusion}

The acute problem of consumption of illegal drug is increasing in Brazil. Most of the studies in Brazil deal with understanding the pattern of drug consumption, while keeping systematic understanding of the causes and consequences untouched. This paper thus tried to explain the causes and consequences of the rising trend of drug 
consumption, especially among women in Brazil. In general, its geographic position, demographic shift, affluence as well as changing social norms play important role as instigators for growing drug consumption and business. Drug consumption, what used to be male phenomenon is diffusing among the female gender as well. For women, this trend is rising due to increasing participation in labor market as well as rising phenomenon of single mothers in the society. This study also shows rising trend of drug consumption among young students of both genders over the decades. Patriarchal supremacy in the society is replicated and reinforced through the environment of drug business that makes the system even crueler for females. This study shows female students users surpass male students in substances like Tranquilizers, Analgesics and Amphetamine which indicates their submission to the social demand of becoming 'calm and skinny' in order to attract male members of the society. As a result of these, the impact of women entering in drug business and consumption appears to be costlier for themselves, for their family as well as for the overall society, through rising prostitution, family break down and growing incarceration rate. At the face of existing weak protective mechanisms, the solution lies on creative and pragmatic policy options such as: incorporation of religion and drug education as well effective enforcement of law in Brazilian society in order to get rid of the evil of drug and its negative externalities. One of the limitations of this study is that the gender based data on drug consumption in Brazil is not well developed. More scientific data base can increase further research with multidimensional focus on the causes as well as consequence. Primary data with extensive survey can bring better insight in future regarding factors and drivers of drug involvement of both the genders. Future studies can also specify economic, educational, demographic and geographic pattern among female drug users in order to contribute effective policy suggestion for each group.

\section{References}

All about Plato. (2013). Retrieved from: http://whowasplato.com/?p=134.

Bertoni, N., Burnett, C., Cruz, M.S., Andrade, T., Bastos, I. F., Leal, E. \& Fischer, B. (2014). Exploring sex differences in drug use, health and service use characteristics among young urban crack users in Brazil. International Journal for Equity in Health, Vol. 13:70. Retrieved from: http://www.equityhealthj.com/content/13/1/70.

Boiteux, L. (2011).Drugs and Prisons: The repression of drugs and d the increase of the Brazilian penitentiary population. Washington Office on Latin America and Transnational Institute. Retrievedfrom:http://www.wola.org/sites/default/files/downloadable/Drug\% 20Policy/2011/WOLATNI-Systems_Overload-brazil-def.pdf.

Carlini, E. A., Galduróz, J. C. F., Noto, A. R., \&Nappo, S. A. (2002). First household survey on the use of psychotropic drugs in Brazil: study of the 107 largest cities in the country. São Paulo: CEBRID/UNIFESP.

Fonseca, A.M.; Carlini, C.M.; Oliveira,L.G.; Nap- po S.A.; Moura, Y.G.; Sanchez, Z.V.M. (2007).Second household Survey on the use of psychotropic drugs cocks in Brazil: study of the 108 largest cities in the country- 2005. São Paulo: CEBRID/SENAD - Brazilian Center for Information on Psychotropic Drugs, Department of Psychobiology. UNIFESP - Federal University of São Paulo, Vol. 468

Galduróz, J.C., Noto, A.R., Nappo, S.A., \&Carlini, E.A. (2004). Trends in drug use among students in Brazil: analysis of four surveys in 1987, 1989, 1993 and 1997. Brazilian Journal Of Medical and Biological Research, Vol. 37, pp. 523-31. Retrieved from: http://www.ncbi.nlm.nih.gov/pubmed/15064815

Gender Across Border (GAB). (2011).The Consequences of "Feminizing" Latin America's Drug War.Retrieved from: http://www.gender acrossborders.com/2011/10/04/the-consequences-of\%E2\%80\%9Cfeminizing\%E2\%80\%9D-latin-america\%E2\%80\%99s.

Giacomello, C. (2014). How the Drug Trade Criminalizes women Disproportionately. NACLA magazine: Summer Issue. Retrieved from: https://nacla.org/article/how-drug-trade-criminalizes-women-disproportionately.

Hsu, L. N. \& du Guerny, J. (1995). Towards a gender-sensitive approach to drug demand reduction: a process within the United Nations system. Bull Narc. Vol. 47(1-2), pp.1-14.Retrived from: http://www.ncbi.nlm.nih.gov/pubmed/8904655.

Miraglia, P. (2015). Drugs and Drug Trafficking in Brazil: Trends and Policies. Center for 21st Century Security and Intelligence Latin America Initiative. Retrieved from: http://www.brookings.edu/ /media/Research/Files/Papers/2015/04/global-drug policy/Miraglia-Brazil-final.pdf?la=en.

Misse, M. \& Vargas, J.D., (2010). Drug Use and Trafficking in Rio de Janeiro Some remarks on harm reduction policies .Vibrant, Vol.7, No. 2. Retrieved from: http://www.vibrant.org.br/downloads/v7n2_misse.pdf

National Secretariat for Drug Policies (SENAD).(2010). First Nationwide Survey on the Use of Alcohol, Tobacco and Other Drugs among College Students in the 27 Brazilian State Capitals.Brasilia.Retrieved from: http://www.obid.senad.gov.br/portais/OBID/ biblioteca/documentos/Dados_Estatisticos/Estudantes/328380.pdf.

Nouthe-Djubgang, J., Malonga, J. M., IdoléMékoundé, A. (1995).The cultural and social consequences and effect on families of women's involvement in drug trafficking in Cameroon: crime and imprisonment. UNODC. Retrieved from: http://www.unodc.org/unodcl en/data-and-analysis/bulletin/bulletin_1995-01-01_1_page006.html

Pedroso, R. S., Kessler, F., \&Pechansky, F. (2013). Treatment of female and male inpatient crack users: a qualitative study. Trends in psychiatry and psychotherapy, 35(1), 36-45.Population Reference Bureau (2013).

The World's Youth(2013).Data sheet. Retrieved from: http://www.prb.org/pdf13/youth-data-sheet-2013.pdf

Ribeiro, M., Perrenoud, L.O, Duailibi, S., Duailibi, L.B, Madruga, C., Marques, ACPR. \&Laranjeira, R. (2014). The Brazilian drug policy 
situation: the public health approach based on research undertaken in a developing country. Public Health Reviews, Vol. 35, No. 2.

Sanchez, Z.M., Martins, S.S., Opaleye, E.S., Moura, Y.G., Locatelli, D.P.,\&Noto, A.R. (2011). Social factors associated to binge drinking: a cross-sectional survey among Brazilian students in private high schools. BMC Public Health, Vol.11. Retrieved from: http://www.academia.edu/9407577/Social_factors_associated_to_binge_drinking_a_crosssectional_survey_among_Brazilian_students_in_private_high_schools

Sentencing Council. (March, 2011). Drug Mules: Twelve case studies. Analysis and Research Bulletins. UK. Retrieved from: https://www.sentencingcouncil.org.uk/wp-content/uploads/Drug mules bulletin.pdf

Silva, G. A., Valente, J.G, Almeida, L,M., Moura, E.C., \& Malta, D.C. (2009). Tobacco smoking and level of education in Brazil.Journal of Public Health, Vol.43(Suppl. 2), pp. 48-56. Retrieved from: http://www.scielosp.org/scielo.php?script=sci_arttext\&pid=S0034$89102009000900007 \&$ Ing=en\&tlng=en.10.1590/S0034-89102009000900007.

Sinha, J. W., Cnaan, R. A., \&Gelles, R. J. (2007). Adolescent risk behaviors and religion: Findings from a national study. Journal of adolescence, 30(2), 231-249.

Souza, M. R. R. D., Oliveira, J. F. D., \&Nascimento, E. R. D. (2014). Women's health and the phenomenon of drugs in brazilian magazines. Texto\&Contexto-Enfermagem, 23(1), 92-100.

The Economist. (April 6, 2013). Drugs in Brazil: Cracking up. Retrieved from: http://www.economist.com/news/americas/21575810worlds-biggest-crack-market-seeks-better-way-deal-addicts-cracking-up

The Pew Research Center.(2013). Brazil's Changing Religious Landscape. Retrieved from: http://www.pewforum.org/2013/07/18/brazilschanging-religious-landscape/

The World Bank.(2015). World Development Indicators. Retrieved from: https://www.google.com.my/publicdata/explore?ds=d5bncppjo f8f9_\&met_y=sp_pop_totl\&idim=country:BRA:ARG\&hl=en\&dl=en

UN Women. (2014). A gender perspective on the impact of drug use, the drug trade, and drug control regimes.(2014) Un women policy brief. (pp.1-3). Retrieved from: http://www.unodc.org/documents/ungass2016/Contributions/UN/Gender_and_Drugs_-_UN_ Women_Policy_Brief.pdf

United Nations Office on Drugs and Crime (UNODC).(2014). the World Drug Report 2014.Vienna. Retrieved from: http://www.unodc. org/documents/wdr2014/World_Drug_Report_2014_web.pdf

US Department of State. (2009). Human Rights Report: Brazil 2009. Retrieved From: http://www.state.gov/j/drl/rls/hrrpt /2009/wha/ 136103.htm

Ventura, M., Simas, L., \&Larouzé, B. (2015). Maternity behind bars: in search of citizenship and health. A study on Brazilian law.Journal of Public Health, Vol.31(3),pp. 607-619

Wagner, G.A., Stempliuk, V. A., Zilberman, M.L., Barroso, L.P.,\& Andrade, A.G. (2007). Alcohol and drug use among university students: gender differences. Journal of Psychiatry, Vol.29, No.2, pp. 123-129. Retrieved from: http://www.scielo.br/scielo. php?pid=s1516-44462007000200007\&script=sci arttext

World Health Organization (WHO). (2009). Changing cultural and social norms that support violence. Retrieved from: http://www.who.int/violence_injury_prevention/violence/norms.pdf

Whiteford, H. A., Degenhardt, L., Rehm, J., Baxter, A. J., Ferrari, A. J., Erskine, H. E., ... \&Vos, T. (2013). Global burden of disease attributable to mental and substance use disorders: findings from the Global Burden of Disease Study 2010. The Lancet, 382(9904), 1575-1586. 